\title{
Analysis of recombinant yeast decapping enzyme
}

\author{
MICHELLE STEIGER, ${ }^{1}$ ANNE CARR-SCHMID, ${ }^{2}$ DAVID C. SCHWARTZ, ${ }^{1,3}$ MEGERDITCH KILEDJIAN, ${ }^{2}$ and \\ ROY PARKER ${ }^{1}$
}

${ }^{1}$ Department of Molecular and Cellular Biology \& Howard Hughes Medical Institute, University of Arizona, Tucson, Arizona 85704, USA

${ }^{2}$ Department of Cell Biology \& Neuroscience, Rutgers University, Piscataway, New Jersey 08854-8082, USA

\begin{abstract}
A critical step in the turnover of yeast mRNAs is decapping. Two yeast proteins, Dcp1p and Dcp2p, are absolutely required for decapping, although their precise roles in the decapping reaction have not been established. To determine the function of both Dcp1p and Dcp2p in decapping, we purified recombinant versions of these proteins from Escherichia coli and examined their properties. These experiments demonstrate that copurification of Dcp1p and Dcp2p yields active decapping enzyme under a variety of conditions. Moreover, Dcp2p alone can have decapping activity under some biochemical conditions. This suggests that Dcp2p can be a catalytic subunit of the decapping complex, and Dcp1p may function to enhance Dcp2p activity, or as an additional active subunit. In addition, recombinant Dcp1p/Dcp2p prefers long mRNA substrates and is sensitive to inhibition by sequestration of the $5^{\prime}$ end but not the $3^{\prime}$ end of the substrate. This suggests that Dcp1p/Dcp2p contains an additional RNA-binding site spatially distinct from the active site. Finally, using two RNA-binding proteins that enhance decapping in vivo (Edc1p and Edc2p), we can reconstitute the activation of decapping with recombinant proteins. This indicates that the Edc1 and Edc2 proteins act directly on the decapping enzyme.
\end{abstract}

Keywords: Decapping; turnover; decay; yeast

\section{INTRODUCTION}

The process of mRNA degradation is a common way to control gene expression. Multiple pathways exist in eukaryotic cells for the degradation of polyadenylated mRNAs (for review, see Beelman and Parker 1995). A major RNA decay pathway has been described in yeast where both unstable and stable mRNAs are primarily degraded by a $5^{\prime} \rightarrow 3^{\prime}$ mechanism of mRNA turnover. In this pathway, the first step is shortening of the 3' poly(A) tail (Muhlrad and Parker 1992; Decker and Parker 1993). Once the mRNA has become oligo-adenylated (10-12 As), the mRNA becomes a substrate for a decapping reaction (Muhlrad et al. 1994, 1995). After decapping, the mRNA is rapidly degraded in a $5^{\prime} \rightarrow 3^{\prime}$ direction by the Xrn $1 \mathrm{p}$ exoribonuclease (Hsu and Stevens 1993). Differential stabilities among diverse mRNAs are due to combinatorial variations in the rates of deadenylation and decapping (Muhlrad et al. 1994, 1995; Cao

Reprint requests to: Roy Parker, Department of Molecular and Cellular Biology \& Howard Hughes Medical Institute, University of Arizona, 1007 E. Lowell St., Tucson, AZ 85704, USA; e-mail: rrparker@u.arizona.edu.

Present address: ${ }^{3}$ Department of Molecular Biochemistry \& Biophysics, Yale University, New Haven, CT 06520, USA.

Article and publication are at http://www.rnajournal.org/cgi/doi/ 10.1261/rna.2151403. and Parker 2001). Alternatively, following deadenylation, mRNAs can be degraded in a $3^{\prime}$ to $5^{\prime}$ direction by the cytoplasmic exosome (Jacobs-Anderson and Parker 1998) and the resulting cap structure hydrolyzed by the DcpS scavenger decapping enzyme, which is encoded by the DCS1 gene in yeast (Wang and Kiledjian 2001; Liu et al. 2002).

Decapping is a critical control point in the major decay pathway as it both precedes and permits the degradation of the mRNA body. The decapping reaction in vivo requires two interacting proteins, Dcp1p and Dcp2p (Beelman et al. 1996; Dunckley and Parker 1999). The in vivo activity of this Dcp1p/Dcp2p enzyme is modulated in both positive and negative ways. For example, the efficiency of the decapping reaction is enhanced by the activity of the Patlp/ Lsm1-7p complex and Dhh1p, a member of the DEAD box family of RNA helicases (Bonnerot et al. 2000; Bouveret et al. 2000; Tharun et al. 2000; Coller et al. 2001; Fischer and Weis 2002). In addition, two small RNA-binding proteins, Edclp and Edc2p, can act to stimulate the rate of decapping both in vivo and in vitro (Dunckley et al. 2001; Schwartz et al. 2003). Although not absolutely required for decapping, all these proteins stimulate the decapping of both stable and unstable mRNAs, suggesting they are general activators of the decapping reaction. In contrast, proteins that are in- 
volved in translation initiation are general inhibitors of decapping. For example, the stability of the interaction between the cytoplasmic cap-binding complex and the mRNA cap structure influences how quickly the mRNA is decapped (Schwartz and Parker 1999, 2000; Vilela et al. 2000; Ramirez et al. 2002). Transcript-specific binding proteins that promote or inhibit the decapping reaction can also modulate the decapping rates of individual mRNAs. For example, Puf3p binds to the $3^{\prime}$ UTR of the COX17 mRNA and enhances the rates of both deadenylation and decapping of this transcript (Olivas and Parker 2000).

To understand the control of decapping, a mechanistic understanding of the properties and functions of the Dcp1 and Dcp2 proteins is required. Toward this end, we purified these proteins from Escherichia coli and examined their properties. These experiments demonstrated that Dcp2p alone has decapping activity under some biochemical conditions, but that activity is more robust in the presence of Dcp1p. Moreover, Dcp1p/Dcp2p prefers long mRNA substrates, suggesting that Dcp1p/Dcp2p contains an additional RNA-binding site that is distinct from the active site. Finally, the addition of recombinant purified Edclp or Edc2p stimulates the recombinant decapping enzyme, indicating that the Edc1 and Edc2 proteins act directly on the decapping enzyme.

\section{RESULTS}

\section{Purification of Dcp1p, Dcp2p, and Dcp1p+Dcp2p}

To determine the functional roles of Dcp1p and Dcp2p, we purified the proteins individually or as a complex from $E$. coli. In these experiments, we used a carboxy-terminal truncated version of Dcp2p, referred to as Dcp $2 \Delta C p$. We used this derivative of Dcp2p for two reasons. First, Dcp2 $\Delta C p$ contains the conserved region of Dcp2p and is sufficient to complement a dcp2 $2 \Delta$ strain (Dunckley and Parker 1999). Second, the full-length Dcp2p is particularly prone to proteolysis and difficult to purify (Dunckley and Parker 1999; Dunckley et al. 2001). As reported previously, we were initially unable to obtain any decapping activity from Dcplp or Dcp $2 \Delta \mathrm{Cp}$ under standard decapping conditions when the individual proteins were purified (LaGrandeur and Parker 1998; Dunckley and Parker 1999) (Fig. 1). We did observe a small amount of activity with Dcp2 $2 \mathrm{Cp}$ alone. The significance of this activity, however, was unclear as similar low levels of activity were observed with point mutations in Dcp2 $2 \mathrm{Cp}$, which inactivate the enzyme in vivo (data not shown).

\section{Coexpression of Dcp1p and Dcp2 $\Delta C p$ in E. coli yields decapping activity}

To determine if the combination of Dcp $1 \mathrm{p}$ and Dcp $2 \Delta \mathrm{Cp}$ was sufficient for producing decapping activity, we coexpressed Flag Dcplp and $\mathrm{His}_{6}$ Dcp2 $2 \mathrm{Cp}$ in E. coli and purified over an anti-Flag affinity column. The resulting pu-

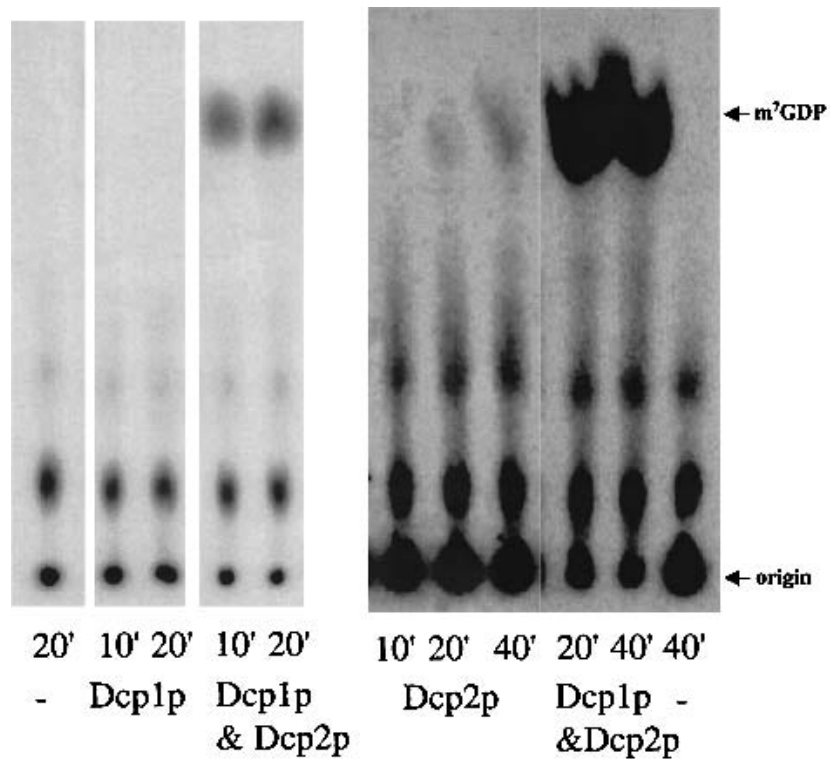

FIGURE 1. Purified fractions from cells expressing Dcp 1p, Dcp $2 \Delta C p$, or Dcplp and Dcp2 $\Delta$ Cp were assayed for decapping activity. Decapping reactions were carried out as described in Materials and Methods in $10 \mu \mathrm{L}$ reactions with 1 fmole of MFA2 substrate and $\sim 20-30 \mathrm{ng}$ of total purified protein. Reaction aliquots were taken and the reaction was stopped at the indicated time points; the reaction products were separated by PEI cellulose TLC. (-) Reaction with no enzyme present.

rified protein fraction contains both Flag Dcplp and $\mathrm{His}_{6}$ Dcp $2 \Delta \mathrm{Cp}$ as shown by both analysis of a silver-stained protein gel and corresponding Western blot analysis (data not shown). The purified fractions were assayed for decapping activity by incubating the protein preparations with caplabeled MFA2 mRNA and detecting the release of $\mathrm{m}^{7} \mathrm{GDP}$ by thin layer chromatography. Purified fractions with Dcplp and Dcp2 $\Delta$ Cp have mRNA decapping activity (Fig. 1). Similar results are obtained using a $\mathrm{Ni}^{2+}$ affinity column, where both Flag Dcplp and $\mathrm{His}_{6}$ Dcp2 $2 \mathrm{Cp}$ copurify and the protein fraction has decapping activity (data not shown). It should be noted that these experiments are done in enzyme excess and are qualitative in nature. These results suggest that the combination of Dcp1p and Dcp2 $\Delta C p$ is sufficient to produce active decapping enzyme.

One caveat with the decapping assay used in Figure 1 is that $\mathrm{m}^{7} \mathrm{GDP}$ comigrates with inorganic phosphate (Pi) (Wang and Kiledjian 2001). Therefore, we confirmed that the decapping reaction using recombinant enzyme was producing $\mathrm{m}^{7} \mathrm{GDP}$ by treating the products of the decapping reaction to nucleotide diphosphate kinase (NDPK). This converts $\mathrm{m}^{7} \mathrm{GDP}$, but not $\mathrm{Pi}$, to $\mathrm{m}^{7} \mathrm{GTP}$, which has a unique migration in the TLC solvent. The product generated by the decapping reaction using the recombinant decapping enzymes is converted to $\mathrm{m}^{7}$ GTP by treatment with NDPK, therefore indicating that the recombinant decapping enzyme is producing the expected reaction product, $\mathrm{m}^{7} \mathrm{GDP}$ (data not shown). In summary, these experiments demonstrated that coexpression of Dcplp and Dcp2 $\Delta$ Cp was suf- 
ficient for producing active recombinant decapping enzyme. To verify that the decapping activity we observed was the same as the actual decapping activity from yeast, we examined the protein requirements for decapping. Dcp2p contains a Nudix, or MutT, motif that is required for decapping in yeast (Dunckley and Parker 1999). Thus, we determined if the Q153E point mutation in the Nudix motif affected the activity of the E. coli-produced enzyme. This point mutation (Q153E) completely blocked mRNA decapping in yeast based on mRNA analysis (Dunckley and Parker 1999). Dcp2 $\Delta$ Cp Q153E still interacts with Dcplp as the mutant protein copurified with Flag Dcplp over an anti-Flag column (data not shown). The resulting purified fraction, however, was unable to decap a cap-labeled MFA2 substrate (Fig. 2). Therefore, similar to the yeast decapping activity, the Nudix motif in Dcp $2 \Delta C p$ is required for activity when the proteins are purified from E. coli.

\section{Recombinant decapping activity prefers longer mRNA substrates and requires an exposed cap}

The ability to produce active decapping enzyme in E. coli allowed us to examine various aspects of the decapping
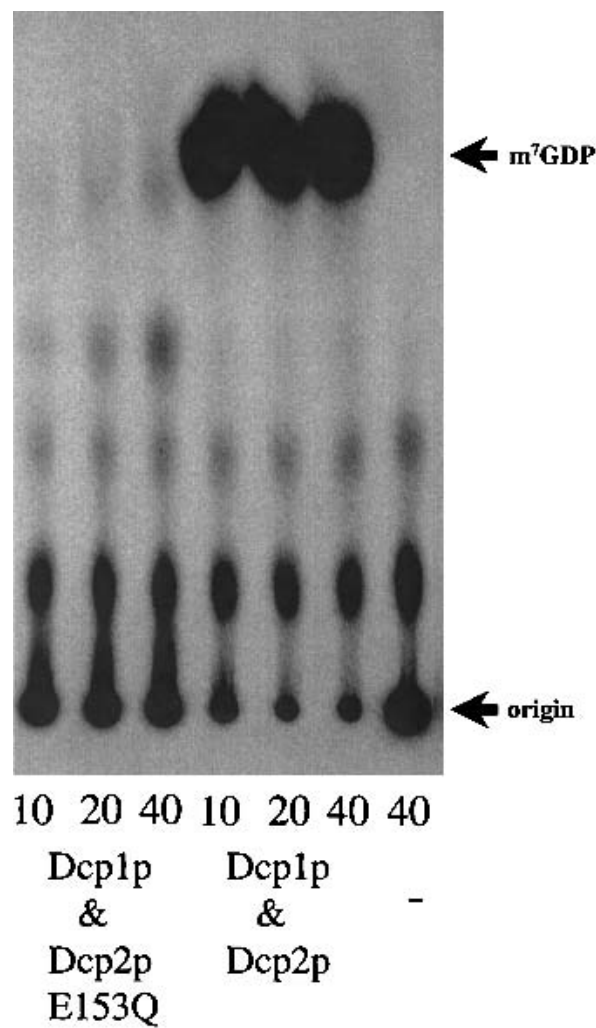

FIGURE 2. Decapping activity requires a normal Nudix motif in Dcp $2 \Delta C p$. Decapping assays analyzed the activity of purified protein fractions where Dcp $2 \Delta C p$ is wild type or has the E153Q mutation. Dcplp is present and wild type in all these protein preparations. Decapping reactions were carried out with 1 fmole MFA2 substrate in a $10-\mu \mathrm{L}$ reaction and $\sim 225 \mathrm{ng}$ of total protein in the purified fractions. Products were separated by PEI cellulose TLC. (-) Reaction with no enzyme present. reaction. For example, the yeast-purified mRNA decapping activity was found to prefer substrates longer than 29 nucleotides (LaGrandeur and Parker 1998). Using the recombinant decapping activity we re-analyzed the size-dependence of the decapping reaction to determine if the requirement is an intrinsic property of the enzyme itself or a feature conveyed by other yeast proteins that copurify. As shown in Figure 3 the decapping activity is maximal with longer mRNA substrates ( $>60 \%$ of the 99 - and 343-nucleotide-long substrate was decapped in $30^{\prime}$ reaction) and is markedly less with shorter substrates (up to $6 \%$ of the 20and 29-nucleotide-long substrate was decapped) and very small amounts of activity were detected with cap analog

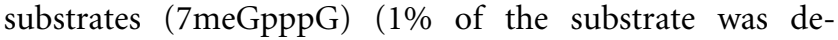
capped). Therefore, the requirement for longer, capped mRNA substrates is an inherent requirement of the Dcplp/ Dcp2p decapping enzyme.

There are two possible explanations for why a longer RNA substrate is preferred by the decapping enzyme. First, it could be that the enzyme contains an RNA-binding site separate from the active site for decapping and a longer substrate can more easily interact with both sites. Alternatively, it could be that the $3^{\prime}$ end of the RNA is required for binding or catalysis, and a longer RNA substrate allows enough flexibility in the substrate for both ends to interact with the enzyme simultaneously.

Two experiments were done to examine the role of the $3^{\prime}$ end in decapping. First, a 26-base DNA oligonucleotide with a $3^{\prime}$ methyl group was ligated onto the $3^{\prime}$ end of the mRNA, thereby replacing the normal RNA $3^{\prime}$ end with DNA sequences. The substrate with a DNA $3^{\prime}$ end was decapped as efficiently as an mRNA with a normal RNA $3^{\prime}$ end (data not shown). In a second experiment, the requirement for different portions of the substrate was tested by the addition of DNA oligonucleotides complementary to the 25 nucleotides at the $5^{\prime}$ end of the substrate, 26 nucleotides in the middle, or the 30 nucleotides at the $3^{\prime}$ end of the substrate. Only the oligonucleotide annealed at the $5^{\prime}$ end of the cap-labeled MFA2 substrate caused a significant decrease in decapping activity with the average inhibition by the $5^{\prime}$ oligo being fivefold (Fig. 4). This argues that sequestration of the $5^{\prime}$ end of the mRNA can inhibit decapping, and raises the possibility that the decapping enzyme must interact with nucleotides near the $5^{\prime}$ end. We interpret these experiments to indicate that the $3^{\prime}$ end is not required for efficient decapping and therefore that the length-dependence is likely to represent an additional RNA-binding site on the decapping enzyme.

\section{The Edc proteins enhance the recombinant decapping activity}

The ability to produce recombinant decapping enzyme allows for analysis of the activity of other proteins implicated from yeast genetic screens for their ability to alter the decapping activity directly. Two small proteins known to en- 


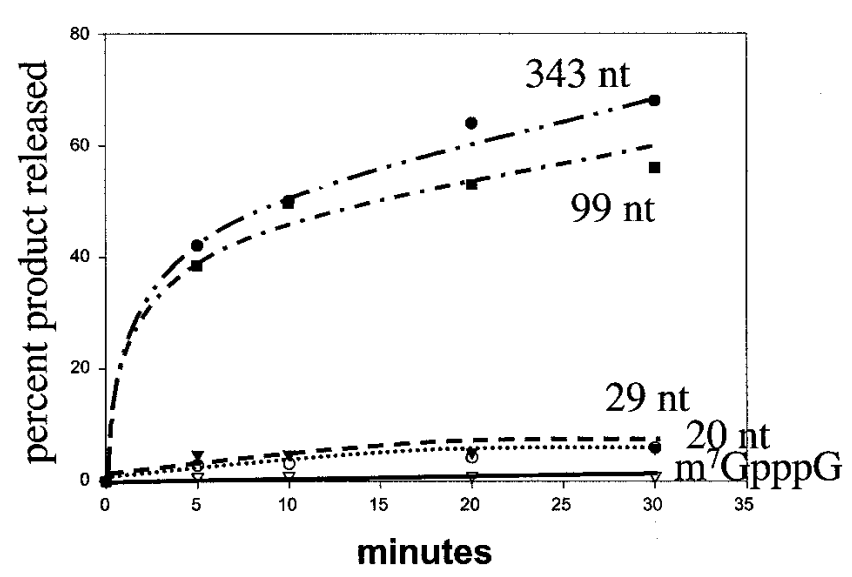

FIGURE 3. Decapping enzyme prefers longer substrates. A graphical representation of the activity observed with recombinant Dcplp/ Dcp $2 \Delta C p$ decapping activity and different-sized MFA2 substrates. The sizes are indicated on the graph: 343 nucleotides (solid circles); 99 nucleotides (solid squares); 29 nucleotides (solid triangles); 20 nucleotides (open circles); and 1 nucleotide (cap analog, $\mathrm{m}^{7} \mathrm{GpppG}$ ) (open triangles). Reactions were carried out as described in Materials and Methods with 1 fmole of the indicated MFA2 substrate, $10-\mu \mathrm{L}$ reaction and $20 \mathrm{ng}$ total protein. Products were separated by PEI cellulose TLC and quantitated with a Molecular Dynamics PhosphorImager.

hance decapping are Edc1p and Edc2p. These proteins were first identified as high copy suppressors of dcp1 and dcp2 point mutations (Dunckley et al. 2001). In addition, Edclp and Edc2p purified from E. coli bind RNA, stimulate the activity of decapping enzyme purified from yeast, but do not show decapping activity themselves (Schwartz et al. 2003). Given this, we used the recombinant Dcpl/ Dcp $2 \Delta C p$ decapping enzyme to determine if Edclp and $E d c 2 p$ act directly on the decapping enzyme.

To test the ability of Edc1p and Edc2p to stimulate decapping activity directly, the recombinant Edc1 and Edc2 proteins were added to decapping reactions with the recombinant Dcp1p/Dcp2 $\Delta$ Cp. It should be noted that in these experiments we significantly reduced the amount of decapping enzyme present in the reactions compared with the earlier experiments to allow any stimulation to be more easily observed. An important result is that both Edclp and Edc2p were independently able to directly stimulate the Dcplp/ Dcp2 $\Delta$ Cp decapping activity (Fig. 5). The recombinant Edc1 protein increases the decapping of a 99-nucleotide-long RNA substrate by an average of 18 -fold. Edc2 protein increases the decapping of a 99-nucleotide-long substrate by, on average, 32 -fold. We interpret these results to indicate that Edclp and Edc2p can activate decapping of the Dcp1p/Dcp2 $\Delta$ Cp enzyme directly and without the requirement for any additional yeast proteins.

\section{Dcp2 $\Delta C p$ contains intrinsic decapping activity}

In the course of this work, the human Dcp2p was isolated and shown to be sufficient for decapping activity when produced in E. coli (Wang et al. 2002). Furthermore, more recent data indicate that the use of manganese in the decapping reaction significantly increases the decapping activity of human Dcp2 (C. Piccirillo and M. Kiledjian, in prep.). Given this, we examined the activity of the yeast Dcp1p, Dcp2 $\Delta$ Cp, and the Dcp1p/Dcp2 $\Delta$ Cp complex, formed by mixing individually purified Dcplp and Dcp2 $\Delta \mathrm{Cp}$, with $\mathrm{Mg}^{2+}$ or $\mathrm{Mg}^{2+}$ and $\mathrm{Mn}^{2+}$ as cofactors using the buffer conditions where human Dcp2p gave activity. An important result was that Dcp $2 \Delta C p$ was clearly active in the presence of $\mathrm{Mn}^{2+}$ (Fig. 6A, lane 7). Consistent with Dcp $2 \Delta C p$ being capable of decapping, low level of decapping can be seen in the presence of $\mathrm{Mg}^{2+}$ under these biochemical conditions. These results suggest that yeast Dcp2 $\Delta C p$ has intrinsic decapping activity. This conclusion was verified by an in-gel assay where Dcp $2 \Delta C p$ was resolved on an SDS-polyacrylamide gel containing cap-labeled RNA. The proteins were renatured as described in Materials and Methods and tested for decapping activity in the standard decapping buffer containing $2 \mathrm{mM} \mathrm{Mn}^{2+}$. As seen in Figure $6 \mathrm{~B}, \mathrm{Dcp} 2 \Delta \mathrm{Cp}$ was able to decap the gel-imbedded RNA as indicated by the zone of radioactive clearing around the protein. Further confirmation that the detected activity is a function of Dcp $2 \Delta \mathrm{Cp}$ is demonstrated by the lack of decapping activity (and clearing) by the Nudix mutant protein Dcp2 $\Delta$ Cp Q153E . These data demonstrate that Dcp2 2 Cp contains decapping activity and is able to function independent of any other protein. However, as seen in Figures 1, 2, and 6A, Dcplp augments this activity.

\section{DISCUSSION}

\section{Dcp1p and Dcp2p constitute the decapping holoenzyme}

Several lines of evidence now suggest that the yeast decapping enzyme can be considered an enzyme complex of

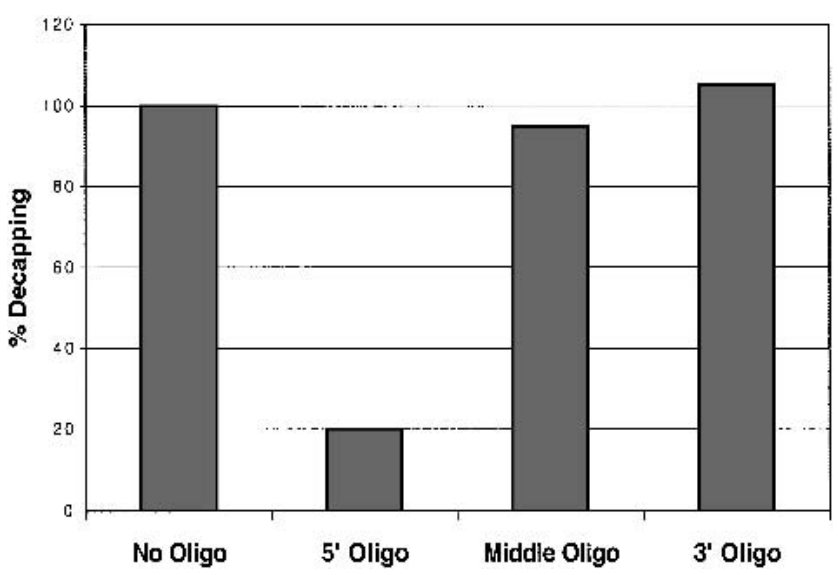

FIGURE 4. Oligonucleotide Inhibition of decapping activity. The effects of adding oligonucleotides complementary to the substrate at different positions are shown following a decapping reaction (see $\mathrm{Ma}$ terials and Methods for sequences). The activity measurements indicated in the graph are normalized to the amount of activity in reactions with no oligo. 
Dcp1p and Dcp2p. First, both of these proteins are absolutely required for decapping in vivo (Beelman et al. 1996; Dunckley and Parker 1999). Second, Dcp1p and Dcp2p show numerous two-hybrid interactions and copurify in several genomic screens (Uetz et al. 2000; Gavin et al. 2002). In addition, direct biochemical purification of either Dcplp or Dcp2p expressed in yeast, or E. coli, copurifies the other partner (Dunckley and Parker 1999; Dunckley et al. 2001; data not shown). Similarly, recent results indicate that the mammalian homologs of Dcp1p and Dcp2p also coimmunoprecipitate, indicating that this interaction is conserved (Lykke-Andersen 2002).

An important issue is the specific roles of the yeast Dcplp and Dcp2p in the process of mRNA decapping. Several observations indicate that Dcp2p is a catalytic subunit capable of cleaving the pyrophosphate cap linkage. This was first suggested by the Nudix motif in Dcp2p, which is required for decapping function, and constitutes a specific protein structure capable of cleaving different substrates of the class XpppY, producing Xpp and pY (Bessman et al. 1996). More importantly, we have now demonstrated that under specific biochemical conditions, $y \mathrm{Dcp} 2 \mathrm{p}$ is capable of decapping an mRNA (Fig. 6A). In addition, yDcp2p can be renatured in an SDS gel to yield decapping activity (Fig. $6 \mathrm{~B})$. These results are consistent with work on the hDcp2p, which is sufficient for decapping activity by itself (Wang et al. 2002). Because the Nudix motif is required for decapping in vivo and in vitro, the simplest interpretation is that the Dcp2p catalyzed decapping reaction is the major catalytic event in decapping.

The conclusion that Dcp2p can catalyze the mRNA decapping alone raises the question of how does Dcplp function in mRNA decapping. Two observations suggest that Dcp1p enhances the activity of Dcp2p. First, Dcp1p is required for all decapping in vivo (Beelman et al. 1996). This indicates that Dcp2p cannot function without Dcp1p in vivo. Second, under conditions where Dcp2p is not sufficient for decapping in vitro, the Dcp1p/Dcp2p complex shows robust decapping activity (Fig. 1). Moreover, as this activity is dependent on the Nudix motif in Dcp2p (Fig. 2), we interpret this reaction to be Dcp2p-catalyzed.

In addition to enhancing Dcp2p activity, several pieces of evidence suggest that Dcplp may also have a catalytic activity. First, decapping activity colocalizes with Dcp1p renatured in gels (LaGrandeur and Parker 1998). Second, separation of Dcp1p and Dcp2p by high salt washes yielded preparations of Dcplp with decapping activity and no detectable Dcp2p (Dunckley et al. 2001). However, neither experiment can rule out the possibility that an undetected fragment of Dcp2p is present and responsible for the observed decapping activity. In addition, recombinant Dcplp has been reported to have decapping activity (Vilela et al. 2000). However, we have been unable to obtain active recombinant Dcplp under a variety of conditions (Fig. 1; data not shown). Given these results, and the clear decapping activity of Dcp2p, we cannot rule out the possibility that the Dcp1p/Dcp2p complex contains two different decapping proteins.

The possibility that the decapping complex may contain two catalytic subunits is intriguing because other enzymes involved in eukaryotic mRNA decay exist in complexes of multiple proteins with similar enzymatic activities. The most dramatic example of this phenomenon is the exosome, which contains 10 different potential $3^{\prime}$ to $5^{\prime}$ exonucleases (Mitchell et al. 1997; Allmang et al. 1999). In addition, in the major yeast deadenylase complex, consisting of Ccr4p, Pop2p, and Not1p-Not5p, both Ccr4p and

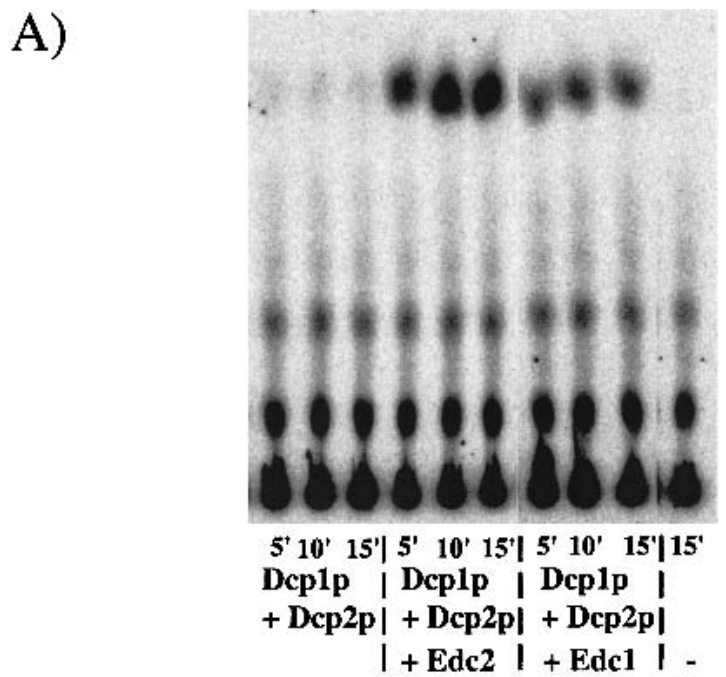

B)

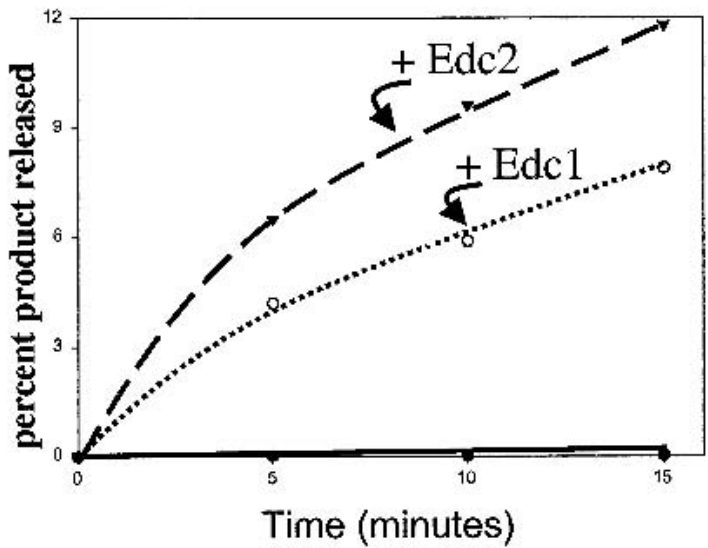

FIGURE 5. Edc proteins stimulate recombinant decapping activity. (A) Decapping reactions were carried out in a $15-\mu \mathrm{L}$ reaction with Edc1p ( 8 fmoles), Edc2p ( 8 fmoles), or BSA present. In these reactions, a lower concentration of Dcp1p/Dcp2 $2 \mathrm{Cp}$ was used to allow the stimulation of activity by Edc proteins to be visualized. The first panel is a PEI cellulose analysis of the reaction products generated after the indicated incubation time. (-) Reaction with no enzyme present. (B) A graphical representation of the data reactions with Edc2p (solid triangles), Edclp (open circles), and no Edc protein but BSA (solid circles) with percent product plotted against time. 
A)

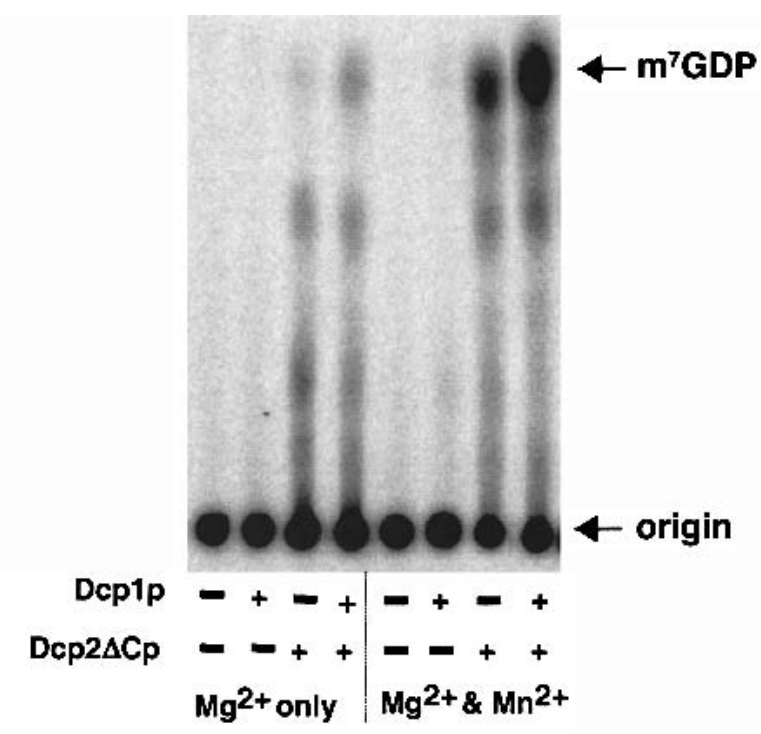

B)

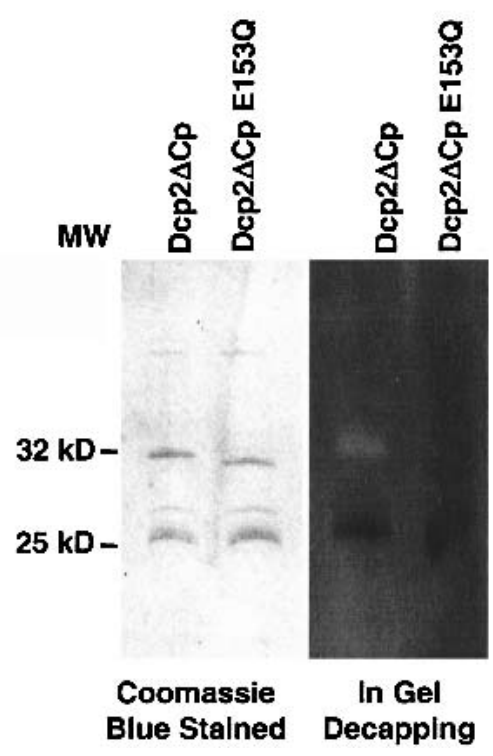

FIGURE 6. $\mathrm{Mn}^{2+}$ stimulates recombinant yeast decapping activity. (A) Decapping reactions were carried out by incubating $300 \mathrm{ng}$ of the indicated histidine-tagged Dcp1p, Dcp2 $\Delta C \mathrm{p}$, or Dcp2 $\Delta$ CpQ153E proteins with cap-labeled $\mathrm{pcP}-\mathrm{G}_{16} \mathrm{RNA}$ for $30 \mathrm{~min}$ at $37^{\circ} \mathrm{C}$ in our standard reaction buffer $\left(\mathrm{Mg}^{2+}\right.$ only) or buffer supplemented with $2 \mathrm{mM}$ $\mathrm{MnCl}_{2}\left(\mathrm{Mg}^{2+}\right.$ and $\left.\mathrm{Mn}^{2+}\right)$. Standards were simultaneously developed and their positions are denoted on the right of the panel. (B) Gelisolated Dcp2p is enzymatically active. Three micrograms of His-Dcp2 $\Delta \mathrm{C}$ and Dcp2 $\Delta \mathrm{C}$ Q153E3 were resolved by a standard SDS/PAGE and visualized by Coomassie blue staining (left panel) or resolved in an identical gel containing cap-labeled pcP-G $\mathrm{G}_{16}$ RNA and renatured and assayed for decapping activity (right panel) (see Materials and Methods). Protein size markers are indicated between the gels.

Pop2p contain exonuclease motifs. In this case, Ccr4p, and perhaps Pop2p, can function as an mRNA deadenylase in vitro (Daugeron et al. 2001; Tucker et al. 2001, 2002; Chen et al. 2002). These observations raise the question of why eukaryotic mRNA decay enzymes are clustered in these complexes. One possibility is that the association of nucleases with similar activity allows for the control of substrate specificity. Specifically, these complexes may allow the cell to limit multiple nucleases simultaneously from acting on inappropriate substrates as well as coordinate their activity with correct substrates.

\section{Modulation of decapping activity}

One of the interesting properties of the Dcp1/Dcp2p decapping enzyme is that is shows greater activity on longer mRNA substrates. This was first reported with the enzyme purified from yeast (LaGrandeur and Parker 1998) and has now been extended to recombinantly produced enzyme (Fig. 4). This indicates the length preference is a property of the enzyme and cannot be attributed to any copurifying proteins. Consistent with this view, the recombinant human Dcp2p decapping activity also prefers longer substrates (Wang et al. 2002). The preference for a longer substrate implies that the Dcp2p also contains a site for binding RNA distinct from the active site. By filling this site, the activity of decapping would be enhanced, either by more efficient interaction of the substrate and the enzyme, or by inducing conformational changes that activate the decapping enzyme. Such a mechanism might be biologically relevant by dictating a requirement for substantial exposed RNA, which might correspond to an mRNP state targeted for decay, before decapping.

Edclp and Edc2p also activate decapping (Dunckley et al. 2001; Schwartz et al. 2003). We have now shown that this effect is directly on the decapping enzyme and can be reconstituted with recombinant proteins (Fig. 5). In principle, the Edc proteins could enhance decapping by one of two likely mechanisms. First, because Edc1 and Edc2p are RNAbinding proteins, the Edc proteins might stimulate decapping by binding both the mRNA substrate and the Dcplp/ Dcp2p decapping enzyme, thereby enhancing the interaction of the enzyme with the substrate and/or the catalytic rate of the enzyme. Alternatively, and not mutually exclusive, Edc1p or Edc2p could act as allosteric activators of the decapping enzyme independent of any Edc-RNA interaction. In either case, the production of recombinant proteins should allow the clear resolution of the mechanisms and control by these proteins and other activators or inhibitors of decapping.

\section{MATERIALS AND METHODS}

\section{Construction of Flag-Dcp1p and His ${ }_{6}$ Dcp2p overexpression vector}

The plasmid expressing a His-Dcp1p in E. coli (pRP785) was constructed by amplifying Dcplp with PCR primers oRP247 (5'-CAGACGGGATCCTCAGCAAAAGAATCTTTTGG-3') and 
oRP248 (5' -CAGAGAGGCGCCATGACCGAGCAAC-3') and inserting the NarI/BamHI cut fragment into the NarI/BamHI sites of pPROEX-1 (GIBCO/BRL).

The plasmid for overproducing both DCP1 and DCP2 in E. coli, pRP 1071, was constructed as follows. $\mathrm{His}_{6}$ DCP2 $\Delta \mathrm{C}$ gene was created by PCR amplifying DCP2 from pRP 925 with the oligonucleotides oRP1126 (CAGAGAGAGCTCGATGTCACTGCCGC TACGACAC) and oRP 1127 (CAGACGGGATCCTCACTCTTG GCTCGAGGGTACCTG) and inserting the SacI/BamHI-cut PCR product into the SacI/BamHI sites of pPROEX-1 (GIBCO-BRL). FLAG DCP1 gene was obtained from a BglII and BamHI digestion of a pET 5a vector with FLAG DCP1 inserted into the NdeIBamHI sites (a gift from John McCarthy). The BglII and BamHI fragment with FLAG DCP1 was ligated into the BamHI site of pPROEX-1 vector to create pRP1080.

The Q153E mutation was introduced into DCP2 by using the QuikChange site-directed mutagenesis kit (Stratagene) and the oligonucleotides GCATTAGAGAAGTGAAAGAACAAATTG GTTTCGATTTGACGG (oRP 1131) and CCGTCAAATCGAAAC CAATTTGTTCTTTCACTTCTCTAATGC (oRP 1132).

\section{Expression and purification of Flag-Dcp1p and $\mathrm{His}_{6}$ Dcp2 $\Delta$ Cp}

Expression of both genes is controlled from the pPROEX-1 lacZ promoter in $\mathrm{DH} 5 \alpha$ cells. Cells containing pRP1071 or pRP1080 are grown in $750 \mathrm{~mL}$ of LB media containing ampicillin at $37^{\circ} \mathrm{C}$ and cells were induced once the $\mathrm{OD} 600 \mathrm{~nm}$ reached $0.4-0.6$ with $0.6 \mathrm{mM}$ IPTG (isopropyl-b-D-thiogalactopyranoside) for $3 \mathrm{~h}$ at $37^{\circ} \mathrm{C}$. Induced cells were collected by centrifugation at $5000 \mathrm{rpm}$ for $15 \mathrm{~min}$ at $4^{\circ} \mathrm{C}$, washed with water, recollected, and frozen.

Frozen cell pellets were thawed on ice, resuspended in $\sim 4 \mathrm{~mL}$ of sonication buffer (10 mM Tris- $\mathrm{HCl}, \mathrm{pH} 7.5,1 \mathrm{M} \mathrm{KCl}, 2 \mathrm{mM}$ magnesium acetate, $1 \mathrm{mM}$ DTT, $1 \mathrm{mg} / \mathrm{mL}$ lysozyme) in the presence of Mini complete-EDTA free protease inhibitors (La Roche), incubated for $30 \mathrm{~min}$ on ice, then sonicated for four, 15-sec rounds, with $1 \mathrm{~min}$ on ice incubation between rounds. The cell debris was pelleted by centrifugation in a tabletop centrifuge at $11 \mathrm{~K}$ for 10 min. The supernatant was removed and used in the subsequent steps.

The clarified cell lysate was diluted with no salt sonication buffer to a final concentration of $100 \mathrm{mM} \mathrm{KCl}$, it was then bound to anti-Flag affinity resin by mixing $1 \mathrm{~h}$ at $4^{\circ} \mathrm{C}$. Approximately 1 $\mathrm{mL}$ of resin was used for a $750 \mathrm{~mL}$ culture of cells grown, induced, and lysed. The resin was spun down at $2000 \mathrm{rpm}$ for $5 \mathrm{~min}$ at $4^{\circ} \mathrm{C}$; the supernatant was saved as the flow-thru, the resin was poured into a solid support column, and washed with 50 column volumes of wash buffer (10 mM Tris-HCl, pH 7.5, $100 \mathrm{mM} \mathrm{KCl,} 2 \mathrm{mM}$ magnesium acetate, $1 \mathrm{mM}$ DTT). The column was then washed with 10 column volumes of high-salt wash buffer (same as wash buffer but with $700 \mathrm{mM} \mathrm{KCl}$ ) followed by washing with 10 column volumes of wash buffer. Proteins were eluted with wash buffer containing $200 \mu \mathrm{g} / \mathrm{mL}$ FLAG peptide and dialyzed overnight at $4^{\circ} \mathrm{C}$ into $50 \%$ glycerol, $50 \mathrm{mM}$ Tris- $\mathrm{HCl}, \mathrm{pH} 7.5,1 \mathrm{mM}$ DTT, and stored at $-20^{\circ} \mathrm{C}$. Purified protein fractions were analyzed by standard SDS polyacrylamide gel electrophoresis methods on $12 \%$ polyacrylamide gels.

\section{Decapping reactions and analysis on TLC plates}

Cap-labeled MFA2 mRNA substrates of various nucleotide lengths were prepared as previously described (LaGrandeur and Parker 1998). Except the short substrates, 29-, 20-, and 1- (cap analog $\mathrm{m}^{7} \mathrm{GpppG}$ ) nucleotides-long were generated by capping a 99nucleotide-long MFA2 transcript, annealing an oligonucleotide, cleaving the RNA with RNase $\mathrm{H}$ for $1 \mathrm{~h}$ at $30^{\circ} \mathrm{C}$, treating the DNA with DNase I, RNase free (La Roche), and purifying the RNAs by polyacrylamide electrophoresis. The oligonucleotide used for generating the 29-nucleotide MFA2 was the oligonucleotide GATC GGTTGCATTAAGGTTGGTA (oRP 1136), for the 20-nucleotide and cap analog MFA2 mRNA substrates the oligonucleotide was GCATTAAGGTTGGTAGTTATTGTT (oRP 1135). Cap-labeled pcP- $\mathrm{G}_{16}$ RNA corresponding to the pcDNA3 polylinker with a G-track of 16 guanosines was prepared as previously described (Wang and Kiledjian 2001).

Decapping reactions were carried out as previously described (LaGranduer and Parker 1998) except the reaction buffer consisted of $50 \mathrm{mM}$ Tris- $\mathrm{HCl}, \mathrm{pH} 7.5,5 \mathrm{mM} \mathrm{MgCl}_{2}, 50 \mathrm{mM} \mathrm{NH}_{4} \mathrm{Cl}$, and $1 \mathrm{mM}$ DTT and each reaction contained $\sim 1$ fmole of the indicated MFA2 substrate. Reactions were stopped by mixing with $1 \mu \mathrm{L}$ of $0.5 \mathrm{M}$ EDTA to the reaction aliquot and placing on ice. Products were separated on a PEI Cellulose thin layer chromatography plate (Selecto) in $0.45\left(\mathrm{NH}_{4}\right)_{2} \mathrm{SO}_{4}$ and detected with a Molecular Dynamics PhosphorImager. For Figure 6, the decapping reaction buffer consisted of $10 \mathrm{mM}$ Tris- $\mathrm{Hcl}$ (pH7.5), $100 \mathrm{mM}$ K-Ac, $2 \mathrm{mM} \mathrm{Mg-Ac,} 2 \mathrm{mM}$ DTT, $0.1 \mathrm{mM}$ Spermine, and each reaction contained $0.5 \times 10^{6} \mathrm{cpm}$ of cap labeled $\mathrm{pcP}-\mathrm{G}_{16}$ RNA. Five microliters of the $20 \mu \mathrm{L}$ reaction products was separated on a PEI Cellulose thin layer chromatography plate (Sigma) in 0.75 $\mathrm{LiCl}$ and detected as above.

Decapping reactions with a DNA oligonucleotide inhibitor were performed as described above with the MFA2 mRNA substrate that is 99 nucleotides long and $\sim 0.6$ ngrams of purified decapping protein. The oligonucleotide used to inhibit the $5^{\prime}$ end was GT TGTATGAAGATGATAGCTCGCCC (oRP 1137). The oligonucleotide used to inhibit the $3^{\prime}$ end was CTTTTCAGAGGATT TATCCTTCTGAGTGGC (oRP 1138). The oligonucleotide used to inhibit the middle, complements $\sim 45$ nucleotides from the $5^{\prime}$ end, GTGTGGAAGCAGTGGTGATCGGTTGC (oRP 1130). In each case, the oligonucleotide was used at a variety of concentrations with the results shown in the figure at a concentration of 6 pmoles.

Purification and characterization for the Edc proteins used here are described in Schwartz et al. (2003). Reactions with Edclp and Edc2 $p$ were performed as described above with $\sim 0.24$ ngrams of decapping enzyme; reactions without either Edc protein added had an equal amount of BSA added in the same buffer as the Edc proteins were stored in (20 mM HEPES, pH 7.5 and $50 \mathrm{mM} \mathrm{KCl})$ to keep the amount of protein the same in all reactions.

\section{In-gel decapping assays}

In-gel decapping assays were carried out with $3 \mu \mathrm{g}$ each of Dcp $2 \Delta$ Cp or Dcp $2 \Delta$ CpQ153E resolved on either a standard $15 \%$ SDS-PAGE gel or a $15 \%$ SDS-PAGE gel containing cap-labeled pcP-G ${ }_{16}$ RNA $\left(1 \times 10^{6} \mathrm{cpm}\right)$ immobilized in the running gel. The two SDS-PAGE gels were subjected to electrophoresis under identical conditions and proteins in the unlabeled gel were visualized 
by Coomassie blue staining. Proteins in the cap-labeled RNAcontaining gel were renatured at $4^{\circ} \mathrm{C}$ as described in LaGrandeur and Parker (1998) and assayed for decapping activity at $30^{\circ} \mathrm{C}$ in the following buffer: (10 mM Tris-Hcl (pH7.5), $100 \mathrm{mM} \mathrm{K-Ac,} 2$ $\mathrm{mM} \mathrm{Mg-Ac,} 2 \mathrm{mM} \mathrm{MnCl}_{2}, 2 \mathrm{mM}$ DTT, $0.1 \mathrm{mM}$ Spermine). The gel was subsequently dried and exposed to Kodak X-ray film.

\section{ACKNOWLEDGMENTS}

We thank Carolyn Decker, Ambro van Hoof, and the Parker laboratories for comments on the manuscript. We thank Chris Piccirillo for sharing unpublished observations. A.C-S. was supported by an American Heart Association fellowship. This work was supported by funds from the Howard Hughes Medical Institute (to R.P.) and National Institutes of Health grants GM45553 to R.P. and DK51611 to M.K.

The publication costs of this article were defrayed in part by payment of page charges. This article must therefore be hereby marked "advertisement" in accordance with 18 USC section 1734 solely to indicate this fact.

Received September 27, 2002; accepted November 4, 2002.

\section{REFERENCES}

Allmang, C., Petfalski, E., Podtelejnikov, A., Mann, M., Tollrevey, D., and Mitchell, P. 1999. The yeast exosome and human PM-Scl are related complexes of 3' $\rightarrow$ ' exonucleases. Genes \& Dev. 13: 2148-2158.

Beelman, C.A. and Parker, R. 1995. Degradation of mRNA in eukaryotes. Cell 8: 179-183.

Beelman, C.A., Stevens A., Caponigro G., LaGrandeur, T.E., Hatfield L., Fortner, D., and Parker, R. 1996. An essential component of the decapping enzyme required for normal rates of mRNA decay in yeast. Nature 38: 642-646.

Bessman, M.J., Frick, D.N, and O’Handley, S.F. 1996. The MutT proteins or "Nudix" hydrolases, a family of versatile, widely distributed, "housecleaning" enzymes. J. Biol. Chem. 271: 25059-25062.

Bonnerot, C., Boeck, R., and Lapeyre, B. 2000. The two protein Patlp (Mrtlp) and Spb8p interact in vivo, are required for mRNA decay, and are functionally linked to Pablp. Mol. Cell. Biol. 20: 5939-5946.

Bouveret, E., Rigaut, G., Shevchenko, A., Wilm, M., and Seraphin, B. 2000. A Sm-like protein complex that participates in mRNA degradation. EMBO J. 19: 1661-1671.

Cao, D. and Parker, R. 2001. Computational modeling of eukaryotic mRNA turnover. RNA 7: 1192-1212.

Chen, J., Chiang, Y.C., and Denis, C.L. 2002. CCR4, a 3'-5' poly(A) RNA and ssDNA exonuclease, is the catalytic component of the cytoplasmic deadenylase. EMBO J. 21: 1414-1426.

Coller, J.M., Tucker, M., Sheth, U., Valencia-Sanchez, M.A., and Parker, R. 2001. The DEAD box helicase, Dhh1p, functions in mRNA decapping and interacts with both the decapping and deadenylase complexes. RNA 7: 1717-1727.

Daugeron, M.C., Mauxion, F., and Seraphin, B. 2001. The yeast POP2 gene encodes a nuclease involved in mRNA deadenylation. Nucleic Acids Res. 29: 2448-2455.

Decker, C.J. and Parker, R. 1993. A turnover pathway for both stable and unstable mRNAs in yeast: evidence for a requirement for deadenylation. Genes \& Dev. 7: 1632-1643.

Dunckley, T. and Parker, R. 1999. The DCP2 protein is required for mRNA decapping in Saccharomyces cerevisiae and contains a functional MutT motif. EMBO J. 18: 5411-5422.

Dunckley T., Tucker, M., and Parker, R. 2001. Two related proteins, Edclp and Edc2p, stimulate mRNA decapping in Saccharomyces cerevisiae. Genetics 157: 27-37.

Fischer, N. and Weis, K. 2002. The DEAD box protein Dhh1 stimulates the decapping enzyme Dcp1. EMBO J. 21: 2788-2797.
Gavin, A.C., Bosche, M., Krause, R., Grandi, P., Marzioch, M., Bauer, A., Schultz, J., Rick, J.M, Michon, A.M., Cruciat, C.M., et al. 2002. Functional organization of the yeast proteome by systematic analysis of protein complexes. Nature 415: 141-147.

Hsu, C.L. and Stevens, A. 1993. Yeast cells lacking $5^{\prime}$ to $3^{\prime}$ exoribonuclease I contain mRNA species that are poly(A) deficient and partially lack the 5' cap structure. Mol. Cell. Biol. 13: 4826-4835.

Jacobs-Anderson, J.S. and Parker, R. 1998. The 3' to 5' degradation of yeast mRNAs is a general mechanism for mRNA turnover that requires the SKI2 DEVH box protein and $3^{\prime}$ to $5^{\prime}$ exonucleases of the exosome complex. EMBO J. 17: 1497-1506.

LaGrandeur, T.E. and Parker, R. 1998. Isolation and characterization of Dcplp, the yeast mRNA decapping enzyme. EMBO J. 17: 1487-1496.

Liu, H., Rodgers, N.D., Jiao, X., and Kiledjian, M. 2002. The scavenger mRNA decapping enzyme DcpS is a member of the HIT family of pyrophosphatases. EMBO J. 21: 4699-4708.

Lykke-Andersen, J. 2002. Identification of a human decapping complex associated with the hUpf proteins in nonsense-mediated decay. Mol. Cell. Biol. (in press).

Mitchell, P., Petfalski, E., Shevchenko, A., Mann, M., and Tollervey, D. 1997. The exosome: A conserved eukaryotic RNA processing complex containing multiple 3'\&rarr:5' exoribonucleases. Cell 91: 457-466.

Muhlrad, D. and Parker, R. 1992. Mutations affecting stability and deadenylation of the yeast MFA2 transcript. Genes \& Dev. 6: 2100-2111.

Muhlrad, D., Decker, C., and Parker, R. 1994. Deadenylation of the unstable mRNA encoded by the yeast MFA2 gene leads to decapping followed by $5^{\prime}$ to $3^{\prime}$ degradation of the transcript. Genes \& Dev. 8: 855-866.

1995. Turnover mechanisms of the stable PGK1 mRNA in yeast. Mol. Cell. Biol. 1: 2145-2156.

Olivas, W. and Parker, R. 2000. The Puf3 protein is a transcript-specific regulator of mRNA degradation in yeast. EMBO J. 19: 6602-6611.

Ramirez, C.V., Vilela, C., Berthelot, K., and McCarthy, J.E. 2002. Modulation of eukaryotic mRNA stability via the cap-binding translation complex eIF4F. J. Mol. Biol. 218: 951-962.

Schwartz, D. and Parker, R. 1999. Mutations in translation initiation factors lead to increased rates of deadenylation and decapping of yeast mRNAs. Mol. Cell. Biol. 19: 5247-5256.

. 2000. mRNA decapping in yeast requires dissociation of the cap binding protein, eukaryotic translation initiation factor $4 \mathrm{E}$. Mol. Cell. Biol. 20: 7933-7942.

Schwartz, D., Decker, C.J., and Parker, R. 2003. The enhancer of decapping proteins, Edclp and Edc2p, bind RNA and directly stimulate the activity of the decapping enzyme. RNA (this issue).

Tharun, S., He, W., Mayes, A.E., Lennertz, P., Beggs, J.D., and Parker, R. 2000. Yeast Sm-like proteins function in mRNA decapping and decay. Nature 404: 515-518.

Tucker, M., Valencia-Sanchez, M.A., Staples, R.R., Chen, J., Denis, C.L., and Parker, R. 2001. The transcription factor associated Ccr4 and Cafl proteins are components of the major cytoplasmic mRNA deadenylase in Saccharomyces cerevisiae. Cell 104: 377-386.

Tucker, M., Staples, R.R., Valencia-Sanchez, M.A., Muhlrad, D., and Parker, R. 2002. Ccr4p is the catalytic sub-unit of a Ccr4/Pop2p/ Notp mRNA deadenylase complex in Saccharomyces cerevisiae. EMBO J. 21: 1427-1436.

Uetz, P., Giot, L., Cagney, G., Mansfield, T.A., Judson, R.S., Knight, J.R., Lockshon, D., Narayan, V., Srinivasan, M., Pochart, P., et al. 2000. A comprehensive analysis of protein-protein interactions in Saccharomyces cerevisiae. Nature 403: 601-603.

Vilela, C., Velasco, C., Ptushkina, M., and McCarthy, J.E. 2000. The eukaryotic mRNA decapping protein Dcp1 interacts physically and functionally with the eIF4F translation initiation complex. $E M B O$ J. 19: 4372-4382.

Wang, Z. and Kiledjian, M. 2001. Functional link between the mammalian exosome and mRNA decapping. Cell 107: 751-762

Wang, Z., Jiao, X., Carr-Schmid, A., and Kiledjian, M. 2002. The $\mathrm{hDcp} 2$ protein is a mammalian mRNA decapping enzyme. Proc. Natl. Acad. Sci. (in press). 

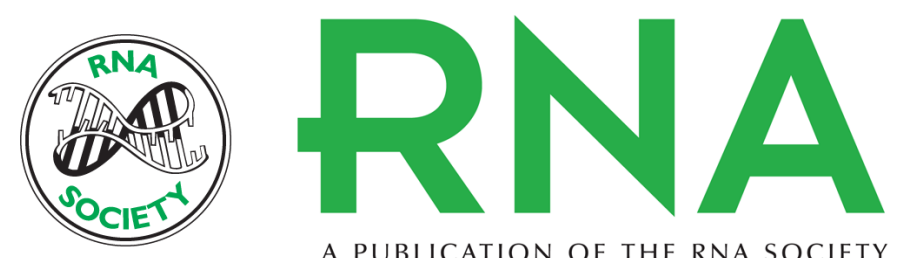

A PUBLICATION OF THE RNA SOCIETY

\title{
Analysis of recombinant yeast decapping enzyme
}

\author{
MICHELLE STEIGER, ANNE CARR-SCHMID, DAVID C. SCHWARTZ, et al.
}

RNA 2003 9: 231-238

References This article cites 32 articles, 21 of which can be accessed free at:

http://rnajournal.cshlp.org/content/9/2/231.full.html\#ref-list-1

\section{License} Email Alerting $\begin{aligned} & \text { Receive free email alerts when new articles cite this article - sign up in the box at the } \\ & \text { Service }\end{aligned}$ top right corner of the article or click here.

To subscribe to $R N A$ go to:

http://rnajournal.cshlp.org/subscriptions 